\title{
FACTORS INFLUENCING MALAYSIAN ESL LEARNERS' ENGAGEMENT IN ACADEMIC WRITING (IN L2)
}

\author{
Ida Fatimawati bt Adi Badiozaman \\ Faculty of Language and Communication, Swinburne University of Technology \\ Sarawak Campus \\ ifaBadiozaman@swinburne.edu.my
}

\begin{abstract}
This paper examines Malaysian learners' engagement in academic writing (AW) in a second language (L2) in a higher learning institution. A quantitative means of exploring students' engagement was incorporated as a starting point to capture a broad cross-sectional snapshot of Malaysian learners' engagement in academic writing and identify pertinent issues of the target population. The quantitative analysis revealed that the majority of the students were highly engaged and that they responded differently in the engagement domains (e.g., high behavioural engagement and low cognitive engagement). The subsequent exploration in the qualitative phase affirmed that the socio-historical aspects of the Malaysian context (e.g., position of English, identity conflicts, and emphasis on education) were also pertinent factors influencing student engagement in the AW class. While a psychological perspective has helped elucidate how engagement dimensions interacted in the learning process, the broader sociocultural aspects helped provide further insights into the role of contextual influences on student engagement in the AW class, and how these were driven by, and also drive motivation towards academic literacy and legitimacy.
\end{abstract}

Keywords: academic engagement, disengagement, academic writing, academic literacy, English as a second language, Malaysia

\section{Introduction}

Over the last three decades, engagement research has been perceived as vital in understanding student learning and development (Coates, 2010; Hu \& Kuh, 2002). Engagement was understood as involvement, time and quality of effort students put into their learning (Pace, 1980). Hu and Kuh (2002) defined student engagement as "the quality of effort students themselves devote to educationally purposeful activities that contribute directly to desired outcomes" (p. 555). Krause (2005) on the other hand defined it as "the time, energy and resources students devote to the activities designed to enhance learning at university" (p. 3). In the same vein, three decades of research have linked students' positive educational outcomes with their 
expended time and effort (Newmann, Wehlage, \& Lamborn, 1992; Pace \& Kuh, 1998; Pascarella, 1991; Wang \& Eccles, 2013)- which explains why these earlier definitions tended to describe engagement predominantly as the students' responsibility.

The understanding of student engagement gradually expanded and institutions were perceived to be accountable for engagement, especially in higher education (Astin, 1993; Pascarella \& Terenzini, 2005). Kuh (2009) maintained that policies and practices of "how the institution allocates its resources and arranges its curricula, other learning opportunities, and support services" (p. 685) could greatly enhance student engagement. Student engagement then began to be perceived as an indicator of collegiate quality (Kuh, Kinzie, Buckley, Bridges, \& Hayek, 2007).

With increasing research and interest in student engagement (Kahu, 2011; Leach, 2014; Wilson, 2010) the understanding of this construct became more developed. Kuh (2009) merged the two views above and defined engagement as, "the time and effort students devote to activities that are empirically linked to desired outcomes of college and what institutions do to induce students to participate in the activities" (p. 683). The academic and non-academic aspects such as level of academic challenge, active and collaborative learning, student-faculty interaction, enriching (consider "enriched") educational experiences and supportive campus environment (Kuh, 2003) formed the basis of many surveys on student engagement such as the National Survey of Student Engagement (NSSE) and Australasian Survey of Student Engagement (AUSSE) (Trowler, 2010). Government reports and policies in countries such as Australia, the UK and the USA, citing student engagement as an educational goal (Harris, 2010) further highlight the value of the construct, particularly in higher learning institutions.

Research on student engagement has ascertained that it is an important factor for improving student retention (James, McInnis, \& Devlin, 2002). Students who feel a sense of disconnection and isolation in their learning experience are prone to withdraw from the course or the institution (Tinto, 2010). This is disconcerting since it not only alludes to disengagement, but also unsuccessful transition to higher learning (Kift \& Moody, 2009; Kift, Nelson, \& Clarke, 2010) and inability to adjust (Heirdsfield, Walker, \& Walsh, 2008) at a crucial stage of the student's academic experience. Indeed, it is crucial that the students' learning experience be supported effectively as it is a means of establishing foundations of successful later years of study (Leach, 2014).

It is evident that the factors that influence student engagement need to be better understood. The focus on academic writing in this study is due to the role of writing in tertiary education (Othman \& Mohamad, , 2009). Students' achievement at tertiary level is evaluated mainly on written assessments; be it in the form of large extended writing (e.g., projects, proposal and reports) or short response essays (e.g. examinations and quizzes). Nonetheless, writing (in English) for Malaysian learners at university level is still reported to be unsatisfactory (Ali \& Yunus, 2004; Che Musa, Koo, \& Azman, 2012), and in comparison with speaking and listening, has been identified to be one of the most difficult skills to master (Yah Awg, Hamzah, \& Hasbollah, 2010). 
Consequently, this study highlights opportunities for improvement within the writing curricula. This is said because it provides a better understanding about the nature of challenges and issues that these tertiary learners face as they learn academic writing in English in Malaysia. This may lead to a more fitting policy for improving the students' academic literacy level. When considering these potential contributions, research on factors that influence student engagement in the Malaysian ESL context becomes an issue worth investigating.

\section{Review of Literature}

\section{Academic Engagement and Disengagement}

According to Hockings, Cooke, Yamashita, McGinty, and Bowl (2008), engagement and disengagement are complex concepts. Consequently, the identification of academically-engaged or disengaged students is an intricate process. It is useful to refer to NSSE, which "focuses on dimensions of quality in undergraduate education and ... assess[es] the extent to which they [students] engage in educational practices associated with high levels of learning and development" (National Survey of Student Engagement, 2011, p. 2). In recent findings, it was identified that effective and frequent use of learning strategies by engaged students included "taking careful notes during class, connecting course content to things already known, and identifying key information from readings" (National Survey of Student Engagement, 2011, p. 16). The survey findings reflect an earlier study by Hockings et al. (2008) in which an academically-engaged student was found to be "intellectually, socially and personally involved in learning what has meaningful outcomes for her" (p. 192).

Since engagement is a process that develops over time and patterns of student engagement may change and evolve (e.g. McInnis, 2001; Wigfield \& Cambria, $2010)$, the notion of engagement as a continuum is propagated. For example, Bryson and Hand (2007) maintained that student engagement exists in a continuum in which students can be engaged and disengaged at various levels and intensity. Hockings et al. (2008) expanded on this by adding that "a student could show signs and degrees of dis/engagement over short or long periods, within a task or session, or over the period of a module or course" (p. 192). Moreover, based on their study, indicators of disengagement may include students who "take a 'surface' approach to learning (copying out notes, focusing on fragmented facts and right answers, jumping to conclusions, accepting)" (p. 350). McInnis (2001) observed that disengagement was detectable through the declining level of commitment to university. In particular, this was evident in the time spent on campus, motivational issues, study habits and also difficulty in managing study workload. Additionally, mismatched expectations (Tinto, 1993) and inadequate preparation for higher learning (Deil-Amen, 2011) have also been argued to be the reasons why students experience academic disengagement.

McInnis (2001) emphasised the need to "reconceptualise the undergraduate experience as a process of negotiated engagement rather than assuming that disengagement is an intractable problem and that students are to blame" (p. 1). This implies that there are many causes that lead to disengagement, other than the 
students themselves. For example, studies have found that student engagement or disengagement is reliant on the nature and quality of feedback and interaction from peers and teachers, as well as the overall experience in the learning context (Kuh, 2003). In some cases, some students are unable to access resources and the opportunities provided by their respective learning institutions (McInnis, 2001); a factor which also led to disengagement and marginalisation.

\section{The perspective of student engagement adopted in the study}

The current study acknowledges that the many perspectives of student engagement (i.e. behavioural and holistic) have contributed great insights to the understanding of the subject's construct. However, the position taken on by this study is the psychological perspective. The psychological perspective of engagement provides an opportunity to focus on the internal processes of engagement in individual students. In doing so, it is hoped that engagement could provide a better understanding of learning academic writing in a second language (L2) in a higher learning institution; in a setting where English is a second language. The psychological perspective views engagement "as an internal psycho-social process that evolves over time and varies in intensity" (Kahu, 2011, p. 761). Furthermore, Fredricks, Blumenfeld and Paris (2004) listed three dimensions of the psychological perspective on student engagement and they are: behavioural, affective and cognitive.

Cognitive engagement is one of the well-researched dimensions of engagement (Fredricks et al., 2004). Newmann et al. (1992) defined cognitive engagement as "a student's psychological investment in and effort directed towards learning, understanding, or mastering the knowledge skills or crafts" (p. 12). This may be observable through students' preference for hard work, willingness to make an investment and also engagement of the mind (Darr, Ferral, \& Stephanou, 2008). Zimmerman (1990) suggests that the intensity of students' cognitive engagement can be identified through self-regulated metacognitive strategies used. In fact, selfregulatory processes have been linked predominantly to the study of academic achievement in terms of strategic learning behaviours, cognitive engagement or specific academic performance measures (Bandura, 1997 as cited in Chong, 2007, p. 63). In this manner, cognitive engagement can help differentiate students' engagement through the range of strategies they adopt (e.g., deep processing strategies and effective strategy use).

Behavioural engagement has three elements: positive conduct, involvement in learning and participation (Fredricks et al., 2004). Furlong et al. (2008) stated that "behavioural engagement is reflected in attendance ... active participation in classes (e.g. asking questions, participating in discussions)" (p. 366). Glanville and Wildhagen (2007) added to the notion of participation by stating that it "encompasses both basic behaviours such as attendance, following school rules and avoidance of disruptive behaviours" (p. 1021). Conversely, Finn and Voelkl (1993) extended the notion of participation to a wider school context (e.g. participating in extracurricular activities) in their participation-identification model. In this model, "most children begin school as willing participants, encouraged to become involved in classroom 
activities by parents and teachers. Continued participation over the years, accompanied by a degree of academic success lead to an internalised sense of identification with school" (Finn \& Cox, 1992, p. 144). This model provides a useful link between emotion and behaviour as part of understanding student engagement and disengagement.

In the psychological perspective, affective dimensions are included as an important component for understanding student engagement. Affective engagement refers to the dimensions of feelings and connection, sense of belonging, safety and attachment (Furlong et al., 2003). Fredricks et al. (2004) also includes "interest, boredom, happiness, sadness and anxiety" (p. 63) as part of affective engagement. Kahu (2011) argues that this dimension of engagement can discern learners' instrumental (e.g. high grades) and intrinsic motivation (e.g., interest).

Overall, engagement provides a crucial framework for understanding students' actions in class. In this study, the term student engagement is used in a broad sense to refer to students' cognitive, behavioural and affective dimensions in relation to academic writing and their participation in academic writing-related tasks. Conversely, the term disengaged is used to characterise students who do not feel that they belong in the Academic Writing class and have withdrawn significantly from learning-related activities.

\section{Engagement with Academic Writing}

Prior to further exploring students' engagement with academic writing in a second language, it is useful to refer to what writing constitutes. Writing requires a series of processes which lead to a completed product. These processes involve multiple cognitively-oriented skills ranging from simple to complex and then finally, demanding, such as comprehension, application and synthesis of new knowledge, reflection and revision that results in a completed manuscript. Thus, when it comes to writing in L2, a "sufficient level of lexical, syntactic and spelling knowledge in the target language" (Ransdell \& Barbier, 2002, p. 3) is required in order to express ideas in the correct linguistic form.

The current literature on academic writing tends to shy away from providing a definition of this subject area. In particular, researchers tend to describe its features, characteristics and function or make comparisons to other writing genres (MacDonald, 1987). Academic writing incorporates elements of hedging (Gillaerts \& Van de Velde, 2010; Swales \& Feak, 2004), nominalisations (Biber \& Gray, 2010) and voice (Matsuda \& Tardy, 2007). Notwithstanding the various operational terms, the general consensus is that academic writing entails high-level cognitive functions (Sheldon, 2009) and grammatical complexity. It involves skills such as identifying, locating, analysing and synthesising information. Furthermore, academic writing necessitates an active production of all the above within the accepted academic writing conventions (Canagarajah, 1999; Steinman, 2003). Zhu (2004) suggests that academic writing "serves different purposes in different courses and requires students to assume different social roles, and that communicative conventions are intricately intertwined with the content for, the aims of, and student roles in writing" (p. 30). Academic writing can therefore be discipline-specific (e.g., Science 
and Humanities) and may vary in terms of its conventions. This has implications for the academic writing class in Malaysian universities, where students may be studying in different disciplines. The challenge is further intensified for $\mathbf{L} 2$ writers because they need to be aware of the conventions of academic writing, be knowledgeable of content, assume a specific role as a writer and be able to write to a particular audience. Thus, it is not surprising that much of the literature on academic writing in a second language links students' inability to engage with weakness in L2 proficiency (Leki, 2011; Leki, Cumming, \& Silva, 2008; Santos, 1988). Anstrom et al. (2010) propagated that that academic English is the reason for the discrepancy between English language learners and English-proficient student. In this light, L2 writers learning academic writing in English not only have to master English, but also gain advanced writing skills

The notion of multiple writer identities, particularly for ESL learners has also been reported to influence students' engagement with academic writing (Li, 2007; Stacey, 2010). In fact, in order to perform successfully in the academic community, learners need to adopt the appropriate writer identity (Ivanic, 2006; Wenger, 1998) in order to gain acceptance as a full member of the community of practice (Huhtala \& Lehti-Eklund, 2010, p. 273). Krause (2005) maintained that "reshaping identity, letting go of long-held beliefs and approaches to learning and social interaction" ( $p$. 10) was necessary for learners' engagement. In other words, their already established identity is challenged to transform, relocate and reposition the self as an academic writer (Harklau, 2006; Hirano, 2008, 2014). This restructuring supports the notion of peripheral participation (Lave \& Wenger, 1991) which believes that, in order to be an expert, you have to start as a peripheral participant and gradually increase your participation. Nonetheless, this restructuring is also contingent on students' willingness to engage and invest in these goals (Petrides \& Frederickson, 2011). Thus, in the current study, the challenge is set for Malaysian learners who have an established and successful L1 writer identity. They may need to adopt a new writer identity, one that is deemed appropriate for the discourse (academic writing) and the larger community (university/ academia) in L2.

This overview of relevant literature not only offered a different way of thinking about engagement, but also highlighted the complexity of the concept when it pertains to L2 learning. In this retrospect, Learning academic writing in a second language entails more than just an accumulation of skills as, there are multiple factors influencing students' engagement with academic writing in L2. Clearly, the learners in the study are not homogenous as their needs, abilities and legitimacy to participate will vary. Exploring the students' experience of learning L2 writing, as indicated by their engagement (or disengagement) in the context is central to this study. It entails numerous complex processes which involve the cognitive, psychological and affective domains. It is anticipated that as a result, the process will be embedded with many challenges, and learners may have to negotiate and reconstruct appropriate and competent writer identities thus necessitating the need to negotiate and reconstruct appropriate and competent writer identities for the learners. 


\section{Methodology}

The study utilised a mixed methods design, in which priority was given to the qualitative phase. This approach was seen as instrumental in providing comprehensive evidence with regard to student engagement in academic writing. Incorporating both qualitative and quantitative approaches was intended to provide various types of data, thus giving the research the rigor, and also quantitative breadth and qualitative depth. Figure 1 provides a visual model of the sequential investigative procedures for the study.

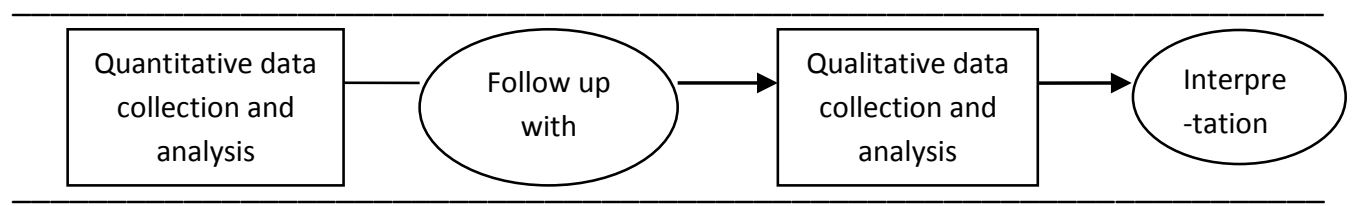

Figure 1. Designing and conducting mixed methods research

(Adapted from Creswell \& Clark, 2010, p. 69)

\section{Phase One}

The first phase of this study utilised a survey questionnaire. Several questionnaires such as Me and My School by Darr et al. (2008) and the Student Engagement Questionnaire (Australasian Survey of Student Engagement [AUSSE], 2008), informed the development of items for the questionnaire. Items were also contextualised to fit into the discipline-specific context of the AW class. Since the aim of the study was to explore factors that influence students' engagement, the psychological perspective provided an opportunity to focus on the internal processes of engagement (behavioural, affective and cognitive) in individual students. For this reason, learners' engagement in the AW class was measured through items such as "I often look for ways to improve my English" (behavioural engagement), "I look forward to going to the writing class" (affective engagement) and "Academic writing helps me to do well in my content papers" (cognitive engagement).

Responses were rated on a 4-point Likert scale ( $1=$ False; $4=$ True). The 4point Likert scale was specifically adopted to avoid having midpoints as an option. In measuring engagement, a student responds to an item in a way that reflects the strength of the item in relation to his/her position with the engagement that is being measured (i.e. cognitive, behavioural and affective). The questionnaire therefore allowed aspects of engagement of the large target population to be systematically identified. Additionally, the data from the survey also helped facilitate the development of the interview protocol in Phase Two.

\section{Phase Two}

The second phase utilised semi-structured interviews. The qualitative data and its analysis would explain in detail, the influences engagement in academic writing (in 
L2) for individual students. In the qualitative phase, each student was interviewed twice to increase the depth and richness of the data. This allowed the complexity and distinctness of engagement to be further understood by the researcher. The interviews took a maximum of one hour per student and were digitally audiorecorded. The gap between the first and second interviews in each case was no more than one week. The interviews were conducted in English and Bahasa Melayu, the native language of the research subjects and the researcher. The interview process was flexible (Janesick, 2000); more questions were added, refined and readjusted in the subsequent interviews due to emergent findings.

The semi-structured interview data was later transcribed using the denaturalised convention (MacLean, Mechthild, \& Alma, 2004). This is a verbatim depiction of speech-perceived to be an antidote to the naturalised transition often used alongside conversation analysis. The emphasis on informational content is particularly relevant to the study as it is concerned with the substance of the interview or specifically "the meanings and perceptions created and shared during a conversation" (Oliver, Serovich, \& Mason, 2005, p. 4). During the study, it became necessary to check the translations of transcriptions to avoid potential inaccuracies and errors. The participants were contacted about this via email to seek their consent and ensure that they were informed. Participants' confidentiality was maintained as the language expert signed a confidentiality agreement.

The analysis of data from this qualitative phase was supported by the use of NVivo 8 software and involved several (but not necessarily distinct) steps, namely, transcription, coding, analysis and interpretation. Transcribed and field notes data were transferred into the NVivo 8 software for further analyses. Upon completing the transcription, Bogdan and Biklen (2007) suggested several steps in developing a coding system. These include: (i) searching for regularities and patterns as well as for topics in the data; (ii) writing down words and phrases to represent these topics and patterns; and (iii) developing a list of coding categories. The identified words and patterns became the initial coding categories for the descriptive data. For the data reduction stage, the process was "dynamic and fluid" (Strauss \& Corbin, 1990, p. 101). It required the researcher to read the whole transcription repeatedly for code refinement. Coding categories had to be limited to ensure that there are no overlaps or redundancies, so major and sub-codes were established. Through NVivo 8 , the systematic analysis of interview data was carried out by grouping coding strips (coded parts) into nodes in the project database, with each node representing a category (see Table 1).

As suggested by Strauss and Corbin (1998) and Bogdan and Biklen (2007), the analysis required several rigorous steps. For coding, the steps were subjected to several rounds, and meaning units were used that "preserve the psychological integrity of the idea being expressed" and "neither fragment the idea into meaningless truncated segments nor confuse it with other ideas that express different themes" (Ratner, 2002, p. 169). The researcher thus coded coherent, related statements as one meaning unit. In cases where participants combined two themes in one sentence, the researcher coded the sentence twice and each theme was placed in two categories. Table 1 presents an overview of the steps involved in coding through NVivo 8 software. 
Table 1

Overview of coding steps using NVivo 8

\begin{tabular}{|c|c|c|}
\hline Step & Procedure & Product \\
\hline $\begin{array}{l}\text { Step } \\
1\end{array}$ & $\begin{array}{l}\text { Relevant parts of each interview were highlighted } \\
\text { and were given a code name based on the theme } \\
\text { they expressed }\end{array}$ & $\begin{array}{l}\text { Free nodes (coding } \\
\text { strips unconnected to } \\
\text { one another) }\end{array}$ \\
\hline Step & Free nodes were compared, revised or deleted & Tree nodes (coding \\
\hline 2 & $\begin{array}{l}\text { Free nodes were clustered based on thematic } \\
\text { affinities into a higher code level }\end{array}$ & $\begin{array}{l}\text { strips that have } \\
\text { category / subcategory } \\
\text { relationship) }\end{array}$ \\
\hline $\begin{array}{l}\text { Step } \\
3\end{array}$ & $\begin{array}{l}\text { All free nodes and tree nodes are compared } \\
\text { across participants } \\
\text { Emergent themes are categorised }\end{array}$ & Casebook / Matrix Query \\
\hline
\end{tabular}

\section{Participants}

The participants in the first phase of the study were selected with opportunity and convenience taken into account (Bryman, 2008). As the chosen university required the students to take an academic writing (AW) course all the students who were currently taking the AW paper were invited to participate. As such, all the 199 students who enrolled in the AW class in that semester (semester one) participated in phase one of this research. The composition of these participants varied as they were from different faculties such as Economics and Business, Engineering, Computer Science and Information Technology, and Social Science. The eight participants in the second phase were selected based on those who expressed interest in the interviews by leaving their email and contact details in the final section of the questionnaire.

\section{Results}

\section{Phase One}

The percentages for each response were calculated for each item. Statistical data obtained from the quantitative method employed allowed the identification of basic tendencies and significant relations with regard to student engagement. These data helped create baseline information and provided reliable explanation on the issue at hand (Drew, Hardman, \& Hosp, 2008). In particular, these statistical data were useful because they could be further investigated in the subsequent phase of the study.

\section{findings on behavioural engagement.}

Engagement items in the questionnaire included statements which could gauge the respondents' behavioural engagement in the AW class. It was inferred through positive conduct, involvement and commitment. The overall mean values of the respondents' behavioural engagement seemed to indicate that they have a 
relatively high behavioural engagement in the AW class. Table 2 summarises the distribution of responses for behavioural engagement items.

Table 2

Distribution of responses for behavioural engagement items

\begin{tabular}{llccccc}
\hline Item & Mean & \multicolumn{4}{c}{$\begin{array}{c}\text { Distribution of } \\
\text { responses \% }\end{array}$} \\
\cline { 3 - 6 } & & F & MF & MT & T \\
\hline E30 & I pay attention in class & 3.24 & 2.4 & 8.2 & 52.4 & 37.1 \\
E29 & When writing gets difficult, I stop trying* & 3.18 & 38.8 & 44.7 & 12.4 & 4.1 \\
E28 & I do as little as possible; I just want to pass* & 3.09 & 34.1 & 46.5 & 14.1 & 5.3 \\
E27 & I work hard in my Academic Writing class & 3.01 & 4.1 & 15.9 & 55.3 & 24.7 \\
E31 & I always participate in class discussions & 2.88 & 5.3 & 25.3 & 45.9 & 23.5 \\
E32 & I prepare two or more drafts of an & 2.69 & 11.2 & 29.4 & 38.8 & 20.6 \\
& assignment before final submission & & & & & \\
\hline
\end{tabular}

Note. $\mathrm{F}=$ False; $\mathrm{MF}=$ Mostly False; $\mathrm{MT}=$ Mostly True; $\mathrm{T}=$ True. Items are arranged from the highest to lowest mean.

* Refers to negatively worded items.

The highest mean value was represented by Item E30, where an overwhelming majority of the students noted that they paid attention in class ( $\mathrm{MT}=52.4 \% ; \mathrm{T}=37.1 \%$ ). These encouraging responses for the behavioural engagement subsection were further supported by Item E29, where the majority of the students reported False (38.8\%) and Mostly False (44.7\%) to the statement "when writing gets difficult, I stop trying"; indicating the determined and persistent nature of the respondents. Very similar responses were reported for Items E28 and E27. The majority of the students disagreed with statement E28 "I do as little as possible; I just want to pass". (MF $=46.5 \%$; $F=34.1 \%$ ). This item (which is intended to gauge the work culture in the AW class) indicated that the majority of the students who responded were of the opinion that merely passing is not sufficient. This is supported by Item E27, which indicated that most students worked hard in the AW class (MT $=55.3 \%$; $\mathrm{T}=24.7 \%)$. In addition, the students responded positively to the statement on class participation (Item E31).

The majority of the students stated that they "always participate in class discussions", implying that commitment and involvement are generally confined within the parameters of the AW class. This finding resonated with earlier findings where the majority of the students indicated that they spent minimal hours studying academic writing independently. An interesting finding was identified for item E32 "I prepare two or more drafts of an assignment before final submission". This item had the lowest mean (2.69) in the behavioural engagement subsection. Although $20.6 \%$ responded True and $38.8 \%$ responded Mostly True to the statement, a considerable number of respondents responded False (11.2\%) and Mostly False (29.4\%). This statistic is alarming, since it demonstrates that the 
academic writing process for the majority of respondents involve not producing drafts or multiple drafts for writing tasks.

\section{Findings on affective engagement}

Statements in the affective engagement subsection are intended to gauge the students' feelings and connections to the AW class. They are represented by learners' positive attitude towards learning, sense of relatedness, and belonging in the AW writing class. The distribution of responses for affective engagement is presented in Table 3.

Table 3

Distribution of responses for Affective Engagement items

\begin{tabular}{|c|c|c|c|c|c|c|}
\hline & \multirow[t]{2}{*}{ Item } & \multirow[t]{2}{*}{ Mean } & \multicolumn{4}{|c|}{$\begin{array}{l}\text { Distribution of } \\
\text { Responses \% }\end{array}$} \\
\hline & & & $\mathbf{F}$ & MF & MT & $\mathbf{T}$ \\
\hline \multicolumn{2}{|c|}{$\begin{array}{l}\text { E36 I think that academic writing is important for } \\
\text { my future }\end{array}$} & 3.64 & 1.2 & 1.2 & 30 & 67.6 \\
\hline E35 & The writing class feels like a waste of time* & 3.58 & 62.9 & 32.9 & 2.9 & 1.2 \\
\hline E38 & In class, I really care that I do my best work & 3.33 & 0 & 10 & 47.1 & 42.9 \\
\hline E34 & I am proud to be in the Academic Writing class & 3.16 & 3.5 & 13.5 & 46.5 & 36.5 \\
\hline E33 & I look forward to my Academic Writing class & 2.67 & 10.6 & 30.6 & 40 & 18.8 \\
\hline
\end{tabular}

Note. $\mathrm{F}=$ False; $\mathrm{MF}=$ Mostly False; $\mathrm{MT}=$ Mostly True; $\mathrm{T}=$ True. Items are arranged from the highest to lowest mean. A* Refers to negatively worded items

Item E36, which aims to gauge students' identification with the AW paper through the statement "I think that academic writing is important for my future" scored the highest mean value (3.64) among the affective engagement items. An overwhelming majority of the students reported True (67.6\%) and Mostly True (30\%) to this statement, indicating that they viewed academic writing as a priority. The identification with what the course has to offer, be it academic literacy or L2 proficiency also highlights issues related to the sense of belonging in the AW class and their academic identity.

This sense of relatedness was further supported by Item E35, where a majority of students disagreed with the statement, "the writing class feels like a waste of time" ( $\mathrm{F}=62.9 \%$. MF= 32.9\%). This infers that the students have an affinity with the AW class and this could have been attributed to the value of the AW subject. The identification with academic writing was also supported by Item E38 in which the majority of the students reported Mostly True (47.1\%) and True (42.9\%) to the statement, "in class I really care that I do my best work". The responses to this item were also indicative of a positive attitude towards learning and the effort and 
students put in as a result of the identifying with AW subject. A majority of the students also reported Mostly True (46.5\%) and True (36.5\%) to Item E34, "I am proud to be in the Academic Writing Class"; further affirming that the participants were engaged affectively and possessed a positive self- concept in the AW class.

\section{Findings on cognitive engagement}

This subsection in the questionnaire aims to capture the respondents' cognitive engagement. Cognitive engagement refers to the psychological investment and effort directed towards learning and understanding. The breakdown of responses for cognitive engagement is presented in Table 4.

Table 4

Distribution of responses for Cognitive Engagement items

\begin{tabular}{|c|c|c|c|c|c|c|}
\hline & \multirow[t]{2}{*}{ Item } & \multicolumn{2}{|c|}{ Mean } & \multicolumn{3}{|c|}{$\begin{array}{l}\text { Distribution of } \\
\text { responses \% }\end{array}$} \\
\hline & & & $\mathbf{F}$ & $M$ & MT & $T$ \\
\hline E40 & $\begin{array}{l}\text { I take care to ensure that my essays } \\
\text { are done properly (e.g. formatting, } \\
\text { referencing) }\end{array}$ & 3.42 & 1.2 & 2.4 & 50 & 46.5 \\
\hline E43 & $\begin{array}{l}\text { I feel that academic writing helps me } \\
\text { to do well in my content papers }\end{array}$ & 3.41 & 1.8 & 4.1 & 45.3 & 48.8 \\
\hline E41 & $\begin{array}{l}\text { I often look for ways to improve my } \\
\text { English writing }\end{array}$ & 3.36 & 1.2 & 4.7 & 50.6 & 43.5 \\
\hline E39 & $\begin{array}{l}\text { Writing in English helps me organise } \\
\text { my ideas }\end{array}$ & 3.24 & 2.9 & 5.3 & 56.5 & 35.3 \\
\hline E42 & $\begin{array}{l}\text { It is easy to organise my thoughts into } \\
\text { sentences in English }\end{array}$ & 2.46 & 12.4 & 42.4 & 32.4 & 12.9 \\
\hline E44 & $\begin{array}{l}\text { I find it hard to express my ideas } \\
\text { effectively in English* }\end{array}$ & 2.31 & 9.4 & 28.8 & 45.3 & 16.5 \\
\hline
\end{tabular}

Note. $\mathrm{F}=$ False; $\mathrm{MF}=$ Mostly False; $\mathrm{MT}=$ Mostly True; $\mathrm{T}=$ True. Items are arranged from the highest to lowest mean.

* refers to negatively worded items.

There are variations in the cognitive engagement in this section. Item E40, which aims to identify the respondents' cognitive engagement with regard to tasks in academic writing, revealed that half of the respondents reported Mostly True $(50 \%)$, while the other half $(46.5 \%)$ reported True to the statement, "I take care to ensure that my essays are done properly". A considerable number of students also agreed that the course had helped them to perform better in content subjects and consequently they would look for ways to improve their writing. A similar positive response was reported for Item E43 "I feel that academic writing helps me to do well in my content papers" where $45.3 \%$ of the students stated Mostly True and $48.8 \%$ stated True. This contrasts with the finding 
on students not seeing the value of successive drafts. Items E39, E42 and E44 further explored cognitive engagement, to see whether the learners faced cognitive challenges in writing due to the level of their English language. The results from Item E39 indicated that for a majority of the respondents, writing in English actually facilitated the organisation of ideas for the writing process $(T=35.3 \%$; $M T$ $56.5 \%)$. However, the actual task of constructing sentences appeared to be the main obstacle. Therefore, to a certain extent, English proficiency may impede the students' cognitive engagement in academic writing as represented by the lowest two mean values ( $\mathrm{E} 42=2.46 ; \mathrm{E} 44=2.31$ ).

Overall, the quantitative analysis identified that a majority of learners appear to be highly engaged students in the AW class, since an overwhelming majority of the respondents agreed that it was important for them to do well in the paper. Although this seemed to reflect the consensus, further analysis of the separate domains indicated that students responded differently in the engagement domains (e.g., high behavioural engagement and low cognitive engagement), which therefore highlights possible contextual influences and affirms the dynamic nature of student engagement. Educational psychologists Bandura (2008) pointed out that learners' beliefs influence their experiences and actions in their learning. Thus, if beliefs predispose action, instances in which students indicated what seems to be lack of effort or cognitive disengagement (e.g., minimal drafts and minimal hours of studying) can be better understood. For example, if a learner's particular belief is that language is an innate ability, this could explain why they invest in it minimally. On the other hand, if students believe that proficiency is not fixed but rather acquired through effort and hard work, they may expend additional effort.

The differences between responses could also be due to the context. Academic Writing was a subject developed for language and academic competency, and is not discipline-inclined. Jary and Lebeau (2009) established that student engagement may vary based on discipline. Thus, in the context of this study, it seemed useful to find out whether the responses elicited on their engagement in AW class were shaped in any way by the nature of the academic writing curriculum and objectives of the course or the respondents' major in their respective faculties.

\section{Linking Phases One and Two}

The goal of the qualitative phase was to elaborate and explain the results in Phase One, further exploring areas potentially related to the formulation of students' engagement in the writing class. Thus, the design of the interview protocol was focused on obtaining a more holistic picture of how learners came to have particular engagement in academic writing. The formulation of the open-ended semistructured interview questions and their respective probes was based on the following themes which emerged from the quantitative findings: (i) the academic writing process, (ii) challenges of academic writing, (iii) the value and relevance of academic writing and (iv) variation of engagement and disengagement (see Figure 2). 


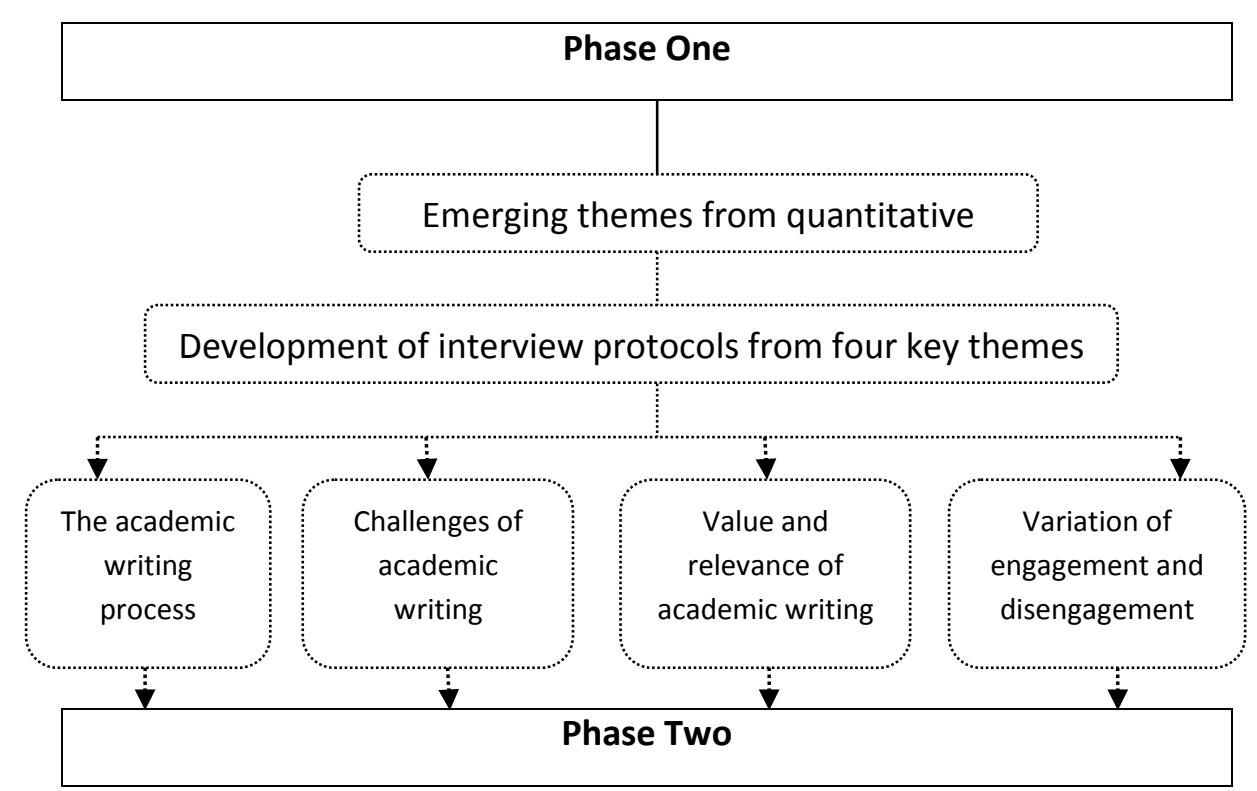

Figure 2. Linking phase one and phase two

(The dotted lines represent the integration of quantitative and qualitative phases)

\section{Phase Two}

The questionnaire results informed and guided the data collection in the qualitative phase of this study. The learners reported in this article are Nurul and Mustafa. The two were selected from the eight students, as their data were particularly rich and detailed, showing how they uniquely conceptualised engagement in academic writing.

\section{Nurul: the outsider looking in}

Nurul is a Malay student, originally from State $X$. When she was interviewed, Nurul was in her final year of study as a Biotechnology student. Nurul spoke only in a local dialect throughout the interview. There were minor code-switching instances (in English) when Nurul felt confident enough of the meaning, but they were limited to only words or short phrases. In the questionnaire, Nurul described her engagement in the AW class as average. Her responses in the interview presented a similar view.

When asked about her educational background, Nurul explained that she had been accepted into a fully residential school in State $X$, after doing well in her primary school exams. In her Form 3 exams she continued to do well (getting an A for English) and was then enrolled into the science stream in her upper secondary school. Although Nurul's parents were very involved in her education and encouraged Nurul and her younger sibling to speak English at home, Nurul refrained from using English and would only respond in Malay. Nurul explained, "I am just not interested to speak in English" (Interview 1). Nurul's quiet demeanour in the first interview could be seen to depict the stereotypical persona of the Asian student (Kiley, 2003). Nevertheless, she was very forthright 
and candid with her answers throughout the interview. This was particularly obvious when she was asked about her experience of learning English and the tasks done in the AW class; "I can say I have never felt motivated to write" (nterview 1), and "As long as it is completed ... done ... I don't really care" (Interview 1).

Based on the responses given, it would be easy to fall into the trap of writing Nurul off as an unmotivated student who showed strong resistance to instruction. Nonetheless, Nurul's resistance and minimal participation seemed to stem from the challenge of the rapidly increasing tasks and the complex learning demands of academic writing. She explained: "Language feature [for academic writing] ... it's different ... we have to ensure formality and objectivity. The tenses used ... it's all quite tedious" (Interview 1). Nurul was also unwilling to accommodate any changes represented by the tasks and participation in the AW class. She explained: "Things that are hard take time. So I stick to things that I know" (Interview 2). In Nurul's case, her inability to cope with the complex demands of academic writing in L2 exemplifies how as part of the learning process, she became marginalised and became an outsider of the AW class community.

Nurul's engagement is complex, as there seemed to be an internal struggle between her reluctance to learn academic writing and the realisation that she still had to pass the paper in order to graduate. This was reflected during the second interview when she spoke about her goal of graduating and finishing her studies. Nurul expressed that, as she was in her third year, she needed to be more focused in completing her Final Year Project. As this was her most important goal, Nurul put in the effort to be more engaged. In relation to her most recent writing task, she commented, "I will start, but after one paragraph I will feel fed-up and then stop. And that will happen many times ... so that will upset me. But then I will tell myself ... I need to do this ... so I will force myself until I finish" (Interview 2). Based on the interview excerpt, Nurul's conflicting goals seemed to imply competing demands, where she had to betray one principle in order to pursue another goal. This conflict appears resolved in her statement: "Final year I have to be serious now ... I have repented ... for my final year project, I will make sure I do my best" (Interview 1).

In Nurul's case, it appears that a goal that has high value is the gaining of proficiency in English for assessment purposes. However, she was not motivated to pursue this if she considered the likelihood of attaining it is low. Thus, Nurul perhaps redefined the parameters of the writing task and aimed for a more proximal goal, where she would get immediate gratification (task completion or merely passing). Therefore, it seems that Nurul's English proficiency issues became an impediment which impacted on her efficacy and willingness to engage in learning academic writing. This resulted in her putting in minimal effort with activities and tasks in the writing class. For example, when Nurul perceived a lesson to be irrelevant or just valueless, she would disengage and produce the absolute minimum. She expressed this concept twice in the interviews: "If I could be invisible I would" (Interview 1) and "I will try my best to be hidden. If I can be transparent I would" (Interview 2). 


\section{Mustafa: holding on to my L1.}

Mustafa is a 21-year-old Biotechnology student. Having several younger siblings still in school, Mustafa explained that he would help them with homework whenever he could; especially if it is a Science or Mathematics subject in English. He clarified that it is his responsibility as an older brother to make sure that they do well in their studies since his parents are unable to do so. He explained, "My parents are not educated" (Interview 1). Due to his parents' circumstances, education seems to be regarded very highly in this family. Mustafa stated that at the age of 12 he was sent to tuition classes so that he could do well in his Ujian Pencapaian Sekolah Rendah (Primary School Evaluation Test). This investment paid off, as Mustafa did well in the exam, and was selected to go to a boarding school at the age of 13. This residential school is religiously-oriented, and learning Arabic is compulsory. Mustafa consistently did well in his studies and, soon after the Penilaian Menengah Rendah (Malay for Lower Secondary Assessment), he was accepted by another residential school to continue his upper secondary studies and continued his academic success in the Sijil Pelajaran Malaysia (Malay for the Malaysian Certificate of Education).

Mustafa listed two main goals that he currently had in mind: to be a lecturer and to be a scientist. Mustafa seemed to believe that academic writing does not play the same role in these goals. When asked whether he felt that academic writing is important for his future, Mustafa initially explained, "No, I don't think academic writing is very important for my future" [as a Scientist] (Interview 1). However, later on he stated, "I want to be a lecturer and I want to do my Masters. So yes, academic writing is directly involved" (Interview 1). Although not all his goals might necessarily have an immediate connection with academic writing, Mustafa was very aware that both goals could only be achieved through outstanding academic success.

Mustafa appreciated that his efforts to become involved in the lesson were recognized by the instructor. He reported that his assessments had consistently received positive feedback and high marks from the instructors, and this in turn made him "more confident about my writing" (Interview 2). This confidence seems to be linked to his engagement in the class, as he was actively involved in answering questions, giving opinions and becoming involved in discussions and presentations in class. He explained, "I can remember in one class, I was the only one who answered her [the instructor] and then she asked others why they were not as involved [as me] in the class" (Interview 2). Despite getting recognition for contributions in the class, Mustafa did not want to be a "popular" student. He emphasised, "I don't need to be popular. There is no benefit. Maybe you will make a lot of friends, but nothing more. Learning is more important" (Interview 2).

The quote above reveals not only Mustafa's high emphasis on learning, but also his satisfaction about being acknowledged by lecturers for participating in educationally purposeful activities in the AW class. While, for specific tasks, he exhibited an individual orientation for engagement, at other times he had a more social orientation. In a language class where learners are continuously trying to improve their skills, such as speaking and writing, Mustafa would take risks and put in the effort for more public participation. When asked whether he felt anxious 
about talking in front of others, Mustafa admitted that the fear would always be there, but, "It prepares me. If I keep presenting and with a lot of practice, the confidence will come and I won't be as nervous the next time" (Interview 2).

\section{Discussion}

Although the psychological perspective (in Phase One) has illuminated significant internal factors influencing student engagement, the socio-historical aspects, especially in the Malaysian context could not be ignored. For example, the findings (in Phase Two) have ascertained that when students attempt to engage, multiple factors (both internal and external) can impede or enable this process. These findings resonate with that of Kahu's (2011), who maintained that the diversity of students' experience attribute to their willingness and ability to engage or disengage.

Within the Malaysian context, great emphasis was put on education due to its post-colonial history. At present, this emphasis is further exacerbated due to the demands of globalisation, thus making academic English language a commodity for graduates, and therefore an important investment. For this reason, two factors emerged as significant in influencing student engagement in the academic writing class: motivation for academic literacy and motivation for academic legitimacy.

\section{The Motivation for Academic Literacy}

The position of English in Malaysia is unique due to socio-historical exigencies and this is manifested in the learners' responses regarding their motivation for learning academic writing in English. The learners engaged in the AW class with a clear sense of purpose and direction. In fact, the majority of them purposefully elected to take the AW subject in order to improve their learning outcomes and overall academic achievement. To illustrate, despite the reported difficulty of AW in L2, students' engagement was still discernible through their perseverance and the range of strategies adopted in the AW class. In this sense, their engagement in the writing tasks and activities in the AW class was influenced by the need to read and write academic texts effectively at university level, not only in the subject of academic writing itself, but also for their own majors and faculties (academic literacy) and personal goals. Upon gaining academic literacy, numerous other opportunities and pathways would be accessible to these learners in terms of furthering their studies at postgraduate level and achieving a promising career in the future.

It is apparent that academic literacy is essential for a successful learning experience at university level, and these students have been motivated to engage in the AW class for the purpose of acquiring academic literacy. The benefits of academic literacy included increased academic writing knowledge; increased English proficiency (for some); increased knowledge for writing research proposals and final year thesis; and other communicative skills relevant to their future career. The promise of employment upon acquiring the knowledge and skills from the AW class was also observable in Mustafa's response. He explained that he wanted to be a lecturer and he wishes to do his Masters "So yes, Academic writing (the paper) is directly involved" (Interview 1). In this sense, the learners' engagement in the AW 
class can be seen as being influenced by their motivation toward academic literacy and its connection with their future goals, be it to further their studies or to gain better career prospects. This finding thus affirms the notion that "people tend to invest in goals that they value more" (Petrides \& Frederickson, 2011, p. 99) as evidenced by the time, energy and effort the students put into learning and into the academic writing-related tasks.

Students' engagement in the AW class, influenced by their motivation of academic literacy, was also ultimately the investment of a young person going into adulthood, whereby the outcomes extend the academic learning experience in the university. In a similar way, learners' investment in educationally purposeful activities has been noted to be advantageous by Kuh (2009):

Engagement increases the odds that any student-educational and social background notwithstanding - will attain his or her educational and personal objectives, acquire the skills and competencies demanded by the challenges of the twenty-first century, and enjoy the intellectual and monetary advantages associated with the completion of the baccalaureate degree. ( $p$. 698)

The high emphasis put on education (Tan, 2012) and scholastic achievement (Komarraju, Karau, \& Ramayah, 2007) in the Malaysian context, and that these students were embedded in a highly academic setting, may also provide reasons for the intensification of these reported engagement during the tertiary education period.

\section{The Motivation for Academic Legitimacy}

Based on the findings, it becomes apparent that learning academic writing in a second language is not only an act of acquiring linguistic and academic literacy, but it is also a negotiation of legitimacy (Chen, 2010; Lave \& Wenger, 1991; Wenger, 1998). This legitimacy is attributed to two main reasons; (i) students are peripheral members who have yet to gain legitimacy within their new academic community, and (ii) students are learning academic writing in English. These two main reasons are intricately linked, as discussed below.

The English language plays an important role and it can be seen clearly as a symbolic resource for students. In fact, Norton (2000) confirmed that language plays the role of a gatekeeper; providing or denying learners access to the learning process, especially for second language learners. Since learners are peripheral members of the academic community, they have to negotiate their way into becoming legitimate peripheral members (Boylan, 2010; Lave \& Wenger, 1991; Warriner, 2010). In the context of the AW class, these students (as newcomers), had to become familiar and adhere to the conventions of academic writing-and the English language students' negotiation for legitimacy was observable from their effortless transition to overcome internal conflicts of conformity. Some students readily accommodated the new writing conventions, participated in class activities and conceptualised the rules of academic writing conventionsvis-à-vis the existing 
academic community. These students' sense of legitimacy was also evident in the reported established networks they had with peers, senior students and instructors. This further raises the possibility of instances which may result in depersonalised relationships and learners relinquishing the actual community (as in the case of Nurul).

One possible reason for the variation of peripherality is learners' proficiency in English. This factor was often responsible for determining the intensity and ability of the students to engage and to access resources and artefacts within the AW class. This is evident in cases where students who had the appropriate level of English proficiency (e.g. Mustafa) or self-efficacy in English were able to engage more effectively in the AW class. On the other hand, students such as Nurul, who wished to acquire academic literacy and also negotiate legitimacy, were unable or limited in terms of their ability to participate in teaching and learning sessions due to their perceived weakness in English proficiency. These two cases further highlight how English proficiency could influence not only their academic legitimacy, but also their academic socialization (Morita, 2009).

Nevertheless, since legitimacy is granted through various ways (Chen, 2010; Norton, 2010), such as practice, activities in the AW class and interaction with the "expert" members, it was evident that the students in the study were doing the best that they could and they continuously tried to participate in the AW class whenever they felt it was possible. For some students, legitimacy may be gained by engaging behaviourally in the class, or by establishing a good relationship with the instructors, and for some other students it may be ensuring that essays were done properly through multiple drafts. The variations within the cognitive, behavioural and affective of engagement in this study therefore depict the various stages that learners were at as they navigated their way from peripheral to fuller participation.

\section{Limitations}

As with all research, this investigation had limitations. Firstly, it must be acknowledged that the information in this study was based on the students' perception of their engagement in the AW class. This study realises that the selfreports from both the questionnaire and semi-structured interviews have shortcomings. For one, it is acknowledged that not all elements of engagement would have been readily accessible through the students' conscious reflections. This may make it difficult to construct a holistic depiction of student engagement and to identify all salient factors within a particular situation. It is also important to recognise the factor of meaning ambiguity in terms of students' understanding of engagement when responding to the questionnaire and interview items. The fact that the students were interviewed based on the overall result of the whole sample may also mean that some of the individual features pertinent to each of the subjects interviewed may have been overlooked. Nonetheless, the data from both methods have provided rich insights into these areas. 


\section{Conclusion}

In this study, the findings have ascertained that when students attempt to engage, multiple factors (both internal and external) can impede or enable this process. Thus, the understanding of student engagement in this study has not only been enriched by awareness of the socio-historical context, but also through the insights into how student engagement can be enhanced and sustained meaningfully through capitalising on internal and external factors that impact on student actions.

In investigating factors that influenced student engagement, it was revealed that the activities related to academic writing are highly regarded by the students. The relevance and value of academic writing and the tasks associated with academic writing enable students to access not only their own disciplinary communities of practice, but also to the overall university community whereby the opportunity for legitimacy is afforded by competency in academic writing. This highlights how the purposeful activities in the AW class were perceived to lead to gains, hence offering a way in to better understand how engagement can be enhanced in the AW class.

Overall, this study reveals that the student engagement in the AW class is shaped by multiple internal and external influences. This finding affirms that in order to fully understand and enhance student engagement in the AW class, all dimensions should be taken into consideration. While a psychological perspective has helped to elucidate how engagement dimensions interacted in the learning process, the broader sociocultural aspects have helped to provide further insights into the role of contextual influences on student engagement in the AW class, and how these have been driven by (and also drive) motivation towards academic literacy and legitimacy. Thus, the understanding of student engagement in this study has not only been enriched by awareness of the participants' socio-historical context, but also through the insights into how student engagement can be enhanced and sustained meaningfully through capitalising on internal and external factors that impact on student actions vis-a-vis to circumvent disengagement.

\section{References}

Ali, Z., \& Yunus, M. (2004). An ESL writing course: Unravelling students' needs and concerns. http://www.melta.org.my/ET/2004/2004-114.pdf

Anstrom, K., DiCerbo, P., Butler, F., Katz, A., Millet, J., \& Rivera, C. (2010). A review of the literature on academic English: Implications for K-12 English language learners. http://www.ceee.gwu.edu

Astin, A. (1993). What matters in college? Four critical years revisited. San Fransisco: Jossey-Bass.

Bandura, A. (2008). Toward an agentic theory of the self. Self-processes, learning, and enabling human potential (Vol. 3, pp. 15-49 ). Charlotte, NC: Information Age Publishing.

Biber, D., \& Gray, B. (2010). Challenging stereotypes about academic writing: Complexity, elaboration, explicitness. Journal of English for Academic Purposes, 9, 2-20. 
Bogdan, R. C., \& Biklen, S. K. (2007). Qualitative research for education: An introduction to theories and methods (5th ed.). Boston: Pearson International Edition.

Boylan, M. (2010). Ecologies of participation in school classrooms. Teaching and Teacher Education, 26, 61-70.

Bryman, A. (2008). Social research methods (3rd ed.). Oxford: Oxford University Press.

Bryson, C., \& Hand, L. (2007). The role of engagement in inspiring teaching and learning. Innovations in Teaching and Education International, 44(4), 349362.

Canagarajah, S. (1999). Resisting linguistic imperialism in English teaching. Oxford: Oxford University Press.

Che Musa, N., Koo, Y. L., \& Azman, H. (2012). Exploring English language learning and teaching in Malaysia. GEMA Online Journal of Language Studies, 12(1), 35-51.

Chen, X. (2010). Identity construction and negotiation within and across school communities: the case of one English-as-a-new-language (ENL) student. Journal of Language, Identity \& Education, 9(3), 163 - 179.

Chong, W. H. (2007). The role of personal agency beliefs in academic self-regulation: An Asian perspective. School Psychology International, 28(1), 63-76.

Coates, H. (2010). Development of the Australasian survey of student engagement (AUSSE). Higher Education, 60, 1-17.

Creswell, J. W., Plano Clark, V., Gutmann, M., \& Hanson, W. (2003). Advanced mixed methods research design. In A. Tashakkori \& C. Teddlie (Eds.), Handbook of mixed methods on social and behavioral research (pp. 209-240). Thousand Oaks, California: Sage.

Darr, C., Ferral, H., \& Stephanou, A. (2008, January). The development of a scale to measure student engagement. Paper presented at the 3rd International Rasch Measurement Conference, Perth, Australia.

Deil-Amen, R. (2011). Socio-academic integrative moments: Rethinking academic and social integration among two-year college students in career-related programs. Journal of Higher Education, 82(1), 54-91.

Drew, C., Hardman, M., \& Hosp, J. (2008). Designing and conducting research in education. Los Angeles, California: Sage.

Finn, J. D., \& Cox, D. (1992). Participation and withdrawal among fourth-grade pupils. American Educational Research Journal, 29(1), 141-162. doi: 10.3102/00028312029001141

Finn, J. D., \& Voelkl, K. E. (1993). School characteristics related to student engagement. The Journal of Negro Education, 62(3), 249-268.

Fredricks, J. A., Blumenfeld, P. C., \& Paris, A. H. (2004). School engagement: Potential of the concept, state of the evidence. Review of Educational Research, 74(1), 59-109.

Furlong, M. J., \& Christenson, S. L. (2008). Engaging students at school and with learning: A relevant construct for all students. Psychology in the Schools, 45(5), 365-368.

Furlong, M. J., Whipple, A. D., St. Jean, G., Simental, J., Soliz, A., \& Punthuna, S. (2003). Multiple contexts of school engagement: Moving toward a unifying 
framework for educational research and practice. The California School Psychologist, 8, 99-114.

Gillaerts, P., \& Van de Velde, F. (2010). Interactional metadiscourse in research article abstracts. Journal of English for Academic Purposes, 9(2), 128-139. doi: 10.1016/j.jeap.2010.02.004

Glanville, J. L., \& Wildhagen, T. (2007). The measurement of school engagement. Educational and Psychological Measurement, 67(6), 1019-1041.

Harklau, L. (2006). From the "Good kids" to the "Worst": Representations of English language learner across educational settings. In P. K. Matsuda, M. Cox, J. Jordan \& C. Ortmeier-Hooper (Eds.), Second-language writing in the composition classroom (pp. 103-130). Boston: St. Martins.

Harris, L. (2010). Delivering, modifying or collaborating? Examining three teacher conceptions of how to facilitate student engagement. Teachers and Teaching: Theory and Practice, 16(1), 131 - 151.

Heirdsfield, A. M., Walker, S., \& Walsh, K. M. (2008). Enhancing the first year experience - Longitudinal perspectives on a peer mentoring scheme. http://eprints.qut.edu.au/12150/

Hirano, E. (2008). Learning difficulty and learner identity: A symbiotic relationship. ELT Journal, 63(1), 33-41.

Hirano, E. (2014). Refugees in first-year college: Academic writing challenges and resources. Journal of Second Language Writing, 23(0), 37-52. doi: http://dx.doi.org/10.1016/j.jslw.2014.01.001

Hockings, C., Cooke, S., Yamashita, H., McGinty, S., \& Bowl, M. (2008). Switched off? A study of disengagement among computing students at two universities. Research Papers in Education, 23(2), 191-201.

Hu, S., \& Kuh, G. (2002). Being (dis)engaged in educationally purposeful activities: The influences of student and institutional characteristics. Research in Higher Education, 43(5), 555-575.

Huhtala, A., \& Lehti-Eklund, H. (2010). Writing a new self in the third place: Language students and identity formation. Pedagogy, Culture \& Society, 18(3), 273 288.

Ivanic, R. (2006). Language, learning and identification. In R. Kiely, P. Rea-Dickins, H. Woodfield \& G. Clibbon (Eds.), Language, culture and identity in applied linguistics (pp. 7-29). London: Equinox.

James, R., Mclnnis, C., \& Devlin, M. (2002). Assessing learning in Australian universities.

http://www.cshe.unimelb.edu.au/assessinglearning/docs/AssessuingLearnin g.pdf

Janesick, V. (2000). The choreography of qualitative research design. In N. Denzin \& Y. Lincoln (Eds.), Handbook of qualitative research (2nd ed., pp. 379-399). Thousand Oaks: Sage.

Jary, D., \& Lebeau, Y. (2009). The student experience and subject engagement in UK sociology: A proposed typology. British Journal of Sociology of Education, 30(6), $697-712$.

Kahu, E. R. (2011). Framing student engagement in higher education. Studies in Higher Education, 38(5), 758-773. 
Kift, S. M., \& Moody, K. E. (2009). Harnessing assessment and feedback in the first year to support learning success, engagement and retention. http://eprints.qut.edu.au/28849/1/28849.pdf

Kift, S. M., Nelson, K. J., \& Clarke, J. (2010). Transition pedagogy: A third generation approach to FYE - A case study of policy and practice for the higher education sector. International Journal of the First Year in Higher Education, 1(1), 1-20.

Kiley, M. (2003). Conserver, strategist or transformer: the experiences of postgraduate student sojourners. Teaching in Higher Education, 8(3), 345356.

Komarraju, M., Karau, S. J., \& Ramayah, T. (2007). Cross-cultural differences in the academic motivation of university students in Malaysia and the United States. North American Journal of Psychology, 9(2), 275-292.

Kuh, G. (2003). What we're learning about student engagement from NNSE. Change, 35(2), 24.

Kuh, G. (2009). What student affairs professionals need to know about student engagement. Journal of College Student Development, 50(6), 683-706.

Kuh, G., Kinzie, J., Buckley, J., Bridges, B., \& Hayek, J. (2007). Piecing together the student success puzzle: Research, propositions, and recommendations. San Fransisco, CA: Jossey-Bass.

Lave, J., \& Wenger, E. (1991). Situated learning: Legitimate peripheral participation. Cambridge: Cambridge University Press.

Leach, L. (2014). Enhancing student engagement in one institution. Journal of Further and Higher Education, 1-25. doi: 10.1080/0309877X.2013.869565

Leki, I. (2011). Learning to write in a second language: Multilingual graduates and undergraduates expanding genre repertoires In R. Manchón (Ed.), Learningto-write and Writing-to-learn in an additional language (pp. 85-110). Netherlands: John Benjamins Publishing Company.

Leki, I., Cumming, A., \& Silva, T. (2008). A synthesis of research on second language writing in English. New York: Routledge.

$\mathrm{Li}, \mathrm{X}$. (2007). Souls in exile: Identities of bilingual writers. Journal of Language, Identity and Education, 6(4), 259-275.

MacDonald, S. P. (1987). Problem definition in academic writing. College English, 49(3), 315-331.

MacLean, L., Mechthild, M., \& Alma, E. (2004). Improving accuracy of transcripts in qualitative research. Qualitative Health Research, 14(1), 113-123.

Matsuda, P. K., \& Tardy, C. (2007). Voice in academic writing: The rhetorical construction of author identity in blind manuscript review. English for Specific Purposes, 26, 235-249.

McInnis, C. (2001). Signs of disengagement? The changing undergraduate experience in Australian universities. Inaugural professorial lecture. (ERIC Document Reproduction Service No. ED 466720). http://eric.ed.gov

Morita, N. (2009). Language, culture, gender, and academic socialization. Language and Education, 23(5), 443-460.

National Survey of Student Engagement. (2011). Fostering student engagement campuswide: Annual Results 2011. 
http://nsse.iub.edu/NSSE_2011_Results/pdf/NSSE_2011_AnnualResults.pdf \#page $=17$

Newmann, F. M., Wehlage, G. G., \& Lamborn, S. (1992). The significance and sources of student engagement. In F. M. Newmann (Ed.), Student engagement and achievement in American secondary schools (pp. 11-39). New York: Teachers College Press.

Norton, B. (2000). Identity and language learning: Gender, ethnicity and educational change. Harlow, England: Longman/ Pearson.

Norton, B. (2010). Language and identity. In N. Hornberger \& S. McKay (Eds.), Sociolinguistics and language education (pp. 349-369). Bristol, UK: Multilingual Matters.

Oliver, D. G., Serovich, J., M., \& Mason, T. L. (2005). Constraints and opportunities with interview transcription: Towards reflection in qualitative research. Social Forces, 84 (2), 1273-1289.

Othman, S. B., \& Mohamad, F. ( 2009, November). Students' response to teacher feedback on multiple-draft compositions in ESL classroom. Paper presented at the International Conference of Teaching and Learning (ICTL), INTI University College, Malaysia. Retrieved from http:///ictl.initimal.edu.my/ict|2009/proceeding/Parallel\%202Sessions\%202/ 2C/2C-03-P64\%20(Malaysia).doc.

Pace, C. (1980). Measuring the quality of student effort. Current Issues in Higher Education, 2(10-16).

Pace, C., \& Kuh, G. (1998). College student experiences questionnaires (4th ed.). Indiana: Indiana University.

Pascarella, E. (1991). The impact of college on students: The nature of the evidence. The Review of Higher Education, 14(1), 453-466.

Pascarella, E., \& Terenzini, P. (2005). How college affect students: A third decade of research. San Fransisco: Jossey-Bass.

Petrides, K. V., \& Frederickson, N. (2011). An application of belief-importance theory in the domain of academic achievement. British Journal of Educational Psychology, 81(1), 97-111.

Ransdell, S., \& Barbier, M. (2002). New directions for research in L2 writing. Dordrecht: Kluwer Acadmic Publishers.

Ratner, C. (2002). Cultural psychology: Theory and method. New York: Plenum.

Santos, T. (1988). Professors' reactions to the academic writing of nonnativespeaking students. TESOL Quarterly, 22(1), 69-90.

Sheldon, E. (2009). From one $I$ to another: Discursive construction of selfrepresentation in English and Castilian Spanish research articles. English for Specific Purposes, 28(4), 251-265.

Stacey, J. (2010). Writer identity while learning discipline-specific academic literacy in an additional language. Southern African Linguistics and Applied Language Studies, 27(3), 345 - 356.

Steinman, L. (2003). Cultural collisions in L2 academic writing. TESL Canada Journal, 20(2), 80-91.

Strauss, A., \& Corbin, J. (1990). Basics of qualitative research: Grounded theoryprocedures and techniques. Newbury Park: Sage Publications. 
Swales, J. M., \& Feak, C. B. (2004). Academic writing for graduate students: Essential tasks and skills. Michigan: University of Michigan Press.

Tan, Y. S. (2012). Democratization of secondary education in Malaysia: Emerging problems and challenges of educational reform. International Journal of Educational Development, 32(1), 53-64. doi: 10.1016/j.ijedudev.2010.11.004

Tinto, V. (1993). Leaving college: Rethinking the causes and cures of student attrition (2nd ed.). Chicago: University of Chicago Press.

Tinto, V. (2010). From theory to action: Exploring the institutional conditions for student retention In J. C. Smart (Ed.), Higher education: Handbook of theory and research (pp. 51-89). Netherlands: Springer.

Trowler, V. (2010). Student engagement literature review. http://www.heacademy.ac.uk/assets/York/documents/ourwork/studenteng agement/StudentEngagementLiteratureReview.pdf

Wang, M.-T., \& Eccles, J. S. (2013). School context, achievement motivation, and academic engagement: A longitudinal study of school engagement using a multidimensional perspective. Learning and Instruction, 28, 12-23.

Warriner, D. S. (2010). Competent performances of situated identities: Adult learners of English accessing engaged participation. Teaching and Teacher Education, 26(1), 22-30. doi: DOI: 10.1016/j.tate.2009.06.003

Wenger, E. (1998). Communities of practice: Learning, meaning and identitiy. Cambridge: Cambdrige University Press.

Wigfield, A., \& Cambria, J. (2010). Students' achievement values, goal orientations, and interest: Definitions, development, and relations to achievement outcomes. Developmental Review, 30(1), 1-35.

Wilson, S. (2010). Student engagement: Student expectations, institutional performance and teacher priorities - An institutional case study http://www.tlri.org.nz/assets/A_Project-PDFs/9261-Zepke/9261-CaseStudy9-.pdf

Yah Awg, N., Hamzah, A., \& Hasbollah, R. (2010, September). Why writing in ESL is difficult for undergraduates in a public university in Malaysia. Paper presented at the Educational and Information Technology (ICEIT), Chongqing, China. http://ieeexplore.ieee.org/xpls/abs_all.jsp?arnumber=5607514\&tag=1

Zhu, W. (2004). Faculty views on the importance of writing, the nature of academic writing, and teaching and responding to writing in the disciplines. Journal of Second Language Writing, 13(1), 29-48. doi: DOI: 10.1016/j.jslw.2004.04.004

Zimmerman, B. (1990). Self-regulated learning and academic achievement: An overview. Educational Psychologist, 21, 3-17. 